\title{
Correction to: SARS-COV-2 infection in children and newborns: a systematic review
}

\author{
Ilaria Liguoro ${ }^{1}$ (D) Chiara Pilotto $^{1} \cdot$ Margherita Bonanni $^{1} \cdot$ Maria Elena Ferrari ${ }^{1} \cdot$ Anna Pusiol $^{1} \cdot$ Agostino Nocerino $^{2}$. \\ Enrico Vidal ${ }^{1} \cdot$ Paola Cogo ${ }^{1}$
}

Published online: 1 February 2021

(C) Springer-Verlag GmbH Germany, part of Springer Nature 2021

Correction to: European Journal of Pediatrics (2020) 179:1029-1046

$$
\text { https://doi.org/10.1007/s00431-020-03684-7 }
$$

The bibliographic information of Zhang et al. 2020 (reference [61]), listed incorrectly in the original published version of the above article. Originally listed as, "61. Zhang H, Kang Z, Gong $\mathrm{H}$, et al (2020) The digestive system is a potential route of 2019-nCov infection: a bioinformatics analysis based on single-cell transcriptomes. bioRxiv 2020.01.30.927806. https://doi.org/10.1101/2020.01.30.927806". This should have been listed as "61. Zhang C, Gu J, Chen Q, Deng NA et al. (2020) Clinical Characteristics of 34 Children with Coronavirus Disease-2019 in the West of China: a Multiple-center Case Series. medRxiv".

The original article has been corrected.

Publisher's note Springer Nature remains neutral with regard to jurisdictional claims in published maps and institutional affiliations.

The online version of the original article can be found at https://doi.org/ 10.1007/s00431-020-03684-7

Ilaria Liguoro

ilarialiguoro@gmail.com

Chiara Pilotto

chiara.pilotto@asufc.sanita.fvg.it

Margherita Bonanni

marghe.bonanni@gmail.com

Maria Elena Ferrari

mary6ferrari@gmail.com

Anna Pusiol

anna.pusiol@asufc.sanita.fvg.it
Agostino Nocerino

agostino.nocerino@asufc.sanita.fvg.it

Enrico Vidal

enrico.vidal@asufc.sanita.fvg.it

Paola Cogo

paola.cogo@uniud.it

1 Department of Medicine DAME - Division of Pediatrics, University of Udine, P.zzale S. Maria della Misericordia, 15, 33100 Udine, Italy

2 Division of Pediatrics, University Hospital of Udine, Udine, Italy 